\title{
Material/ Spiritual Seeding? Problematising Religion and Gullibility in Zimbabwe
}

\author{
Tenson Mabhuya Muyambo \\ ORCID ID: https://orcid.org/0000-0001-6765-5034
}

\begin{abstract}
The media in Southern Africa is inundated by 'strange' events that happen in the church. The events range from congregants who are asked to eat grass; who allow a 'Man of God' to literally walk on their stomachs while lying prostrate on the ground; those who 'generously' donate in church when they do not have enough to eat at home, to those who are raped under the banner of healing. The actions are ordinarily understood by onlookers as either unacceptable levels of tolerance or signs of hopelessness by the congregants. The tendency by onlookers is to quickly pass judgement without an attempt to understand what is going on from the believer's perspective. This chapter utilises in-depth interviews with congregants hoping to understand why some of them behave the way they do. This is done in order to understand them before passing uninformed comments. The chapter found out that the believers see nothing absurd in their behaviour. Whose judgement then matters? The onlookers' or the congregants'? The chapter argues that if we use the phenomenology of religion lens, seeding in the church is not religious gullibility for believers but for scholars/researchers it is religious gullibility that violates certain fundamental human rights.
\end{abstract}

Keywords: seeding, religious gullibility, opium, prosperity gospel, Zimbabwe

\section{Introduction}

The media in Southern Africa, both print and electronic, is inundated by 'strange' happenings in the church. Newspapers report of church followers 
who are said to eat grass by a 'Man of God' and they unquestioningly do so (Chimuka 2017). Some are asked to lie down on their backs and the 'Man of God' literally walk on their stomachs (including pregnant women). Others exceedingly 'donate' in the name of giving unto God when they have no food at home. In some instances, snakes are fed to congregants and we often hear of women having been raped in a bid to get healed or exorcised of evil spirits. These actions are ordinarily understood by onlookers as either unacceptable levels of tolerance or signs of hopelessness by the congregants. The tendency by onlookers is to quickly pass judgement without an attempt to understand what is going on from the believer's perspective. This chapter is an attempt to understand the congregants from their point of view. The chapter answers the following questions: Is it sheer gullibility (naivety) for church believers to behave the way they do? What significance do these believers attach to the socalled 'Man/Woman of God'? Are they justified in doing what they do? In order to find answers to these questions, the chapter discusses the congregants' opinions and views regarding their behaviour towards seeding and the 'Man/Woman of God'. The chapter does this by stating the statement of the problem, conceptualising key terms/phrases, describing the methodology and methods in collecting data, presenting the data and analysing it, and lastly concluding by way of stating the main argument of the chapter.

\section{Statement of the Problem}

Are church members' behaviour in the church a question of religious gullibility/naivety? The media, both print and electronic are inundated by stories that congregants blindly 'seed' in church, eat grass or snakes, and others get raped under the pretext of healing. While onlookers perceive this as sheer religious naivety/ gullibility, the congregants' reasons for doing so need unpacking. What do believers say about their behaviour? Is this behaviour acceptable in other circles? What is the scholars/ researchers' stance on religious gullibility? These are the questions that preoccupy this study.

\section{Conceptual Framework Gullibility}

Chimuka (2017: 49) argues that the term 'gullibility is understood variously as ranging from outright stupidity to indecision raised by epistemic indeterminacy 
of the testimony of others'. He further argues that gullibility is 'unwarranted belief in something ... with no substantiating facts to support it' (Chimuka 2017: 50). In other words, it is 'failure of social intelligence' (Chimuka 2017: 50). Put differently, gullibility is sheer naivety, sheepish acceptance of things without interrogating them. In religious terms, this is a blind belief that often results in one being taken advantage of or manipulated. The definitions imply that gullibility is a fact of life. It is found everywhere, be it in the social, economic, political and religious aspects of humanity. We have all been a victim of gullibility in one way or the other.

\section{Seeding}

To start with, the conceptualisation of 'seeding' itself is contested. Scholars and religious practitioners do not agree on the notion of giving, popularly known as 'seeding' or 'sowing' (Biri 2012). The church in general and Pentecostals in particular believe in giving. This giving is popularly known in church circles as 'seeding/sowing in the church [kudyara mukereke]. For Biri (2012: 8), seeding/sowing comes in various forms such as funding church activities and giving to the 'Man/Woman of God' who, in most cases, is the founder of the church. Believers 'seed' in anticipation of rewards in return.

\section{'Man/ Woman of God'}

The title 'Man of God' denotes a larger-than-life human being. Gunda and Machingura (2013) expend quite some energy and effort in delineating what the phrase 'Man/Woman of God' entails. They argue that 'Man of God' is an outstanding individual. For Glover (2006:452), 'Man of God' is an individual who is literally 'above men'. This brings a sense of a 'mortal above other mortals' (Gunda \& Machingura 2013:19). The 'Man/Woman of God' is therefore a superhuman being with extraordinary qualities that set him/her apart from the rest of the congregation. He/she has certain characteristics that the ordinary man/woman of the congregation does not have.

\section{Methodology}

The study is a qualitative one that seeks to understand why believers of certain congregations behave the way they do. It seeks to gather their views, expe- 
riences and opinions, as well as feelings towards certain behaviours. This study collected data through in-depth interviews from thirty participants who were purposively sampled from Pentecostal movements, since it is Pente-costals who are closely associated with seeding, unlike mainline churches. Ten members (five males and five females) from the Apostolic Faith Mission (A.F.M.), ten members (five males and five females) from Prophecy, Healing and Deliverance Ministries (P.H.D. Ministries) and ten members (five males and five females) from Goodness and Mercy Ministries (G.M.M.) participated in the study. Gender dynamics were considered in the study. In this research, participation was voluntary. De Vaus (2002) advocates that informed consent needs to provide the participants with knowledge of the research purpose and processes; any potential risks or harm; the benefits of the research; how the participants were chosen; and the freedom to withdraw from the research process was granted. Data were analysed using the thematic approach.

The phenomenological approach where the researcher respects the believers' faith was adopted for this study. This perspective argues that there is a need for 'researchers to refrain from imposing their views on religious phenomena' (Chitando, Manyonganise \& Mlambo 2013: 155). The researcher is encouraged to describe religious phenomena accurately and to be sensitive to the point view of the believer. Cognisant of the inherent weaknesses of the phenomenological approach, I applied what Smit and Osborn (2007) terms the Interpretive Phenomenological Analysis (IPA) to explore in detail how believers make sense of their personal and social world of seeding. The main currency for an IPA study is the meanings that particular experiences, events, states hold for participants. This involved a detailed examination of the participants' lifeworld of seeding. At the same time, IPA also emphasises that the research exercise is a dynamic process with an active role for the researcher in that process (Smith \& Osborn 2007). One tries to get close to the participant's personal world, to take, in Conrad's (1987) words, an 'insider's perspective'. This obviously involves a process of interpretative activity. For this study, IPA complements the phenomenology of religion approach.

\section{Research Findings}

\section{Congregants' Perceptions on 'Seeding'}

The concept of 'seeding' is a biblical notion (though it may have equivalents in other religions) where Christians 'generously' plough into the church by 


\section{Tenson Mabhuya Muyambo}

giving money, assets like cars and houses, or even voluntary working for the church like cleaning in the church, doing house chores for the 'Man/Woman of God' and many others. The hope is that all these 'donations' are not in vain. They do this, as the Bible implores them to 'give and it shall come back to you: good measure, pressed down, shaken together and running over ...' (Lk 6:38), meaning that there are returns when one sows a seed into the work of God.

Many respondents (A.F.M., P.H.D. and G.M.M.) unanimously agreed that it was incumbent upon every Christian to 'seed' and they cited biblical verses that make it a requirement to 'seed'. The verses cited the most are Proverbs 11: 24-25, 2 Corinthians 9: 6, and Lk8: 2ff. The underlying theme in these quoted verses is that it is Christian to 'seed' and 'whosoever seedth shall reap bountifully'.

A female respondent from P.H.D. categorically made it clear that 'seeding' in the church was personal and benefited the giver. She shared her experiences where she used to do house chores for the 'Man of God'. She narrated that she had the right qualifications for a profession but could not get one. She decided to spend her time at the pastor's house assisting in things like doing laundry and other household chores. As she was doing this she also prayed for a job, being assisted by the 'Man of God'. After three months of this 'seeding' to the 'Man of God' she was finally rewarded by a job where she took charge of a big company as the chief executive officer. During the interview, she made it clear that her getting the job had nothing to do with her qualification but that it was because she had sown into God and God rewarded her. She was convinced that it was because of what she had done at the pastor's house that granted her the job.

Seeding, therefore, according to many respondents, happens where an individual 'sows seeds' into the work of the church, anticipating something bigger to come out of the seeding. An agricultural metaphor was used to explain how big the proceeds are after seeding in the church. One male respondent stated that seeding in the church is like one who plants a seed in the soil. The seed germinates and produces many seeds, yet it was sown as one seed.

\section{Reasons for Members to 'Seed'}

Interviewees indicated that they 'planted' in the church for various reasons. The reasons ranged from social, religious/spiritual to economic ones. The respondents were insistent that one who 'sows' into the church reaps what she/ 
he has sown. The following subsections are a presentation of the reasons that respondents cited as to why they 'seed' into the church.

\section{Social Factors}

The church as a society keeps cohering when members engage in socially binding activities. Seeding is one such activity. Respondents (A.F.Ml, P.H.Dl and G.M.Ml) were unanimous on the social role of seeding in the church. Seeding was said to bring members of the same denomination together. This resonates with what Dhliwayo (cited in Bulla 2015) says when she admits that seeding helps with the upkeep of the church. It involves giving in cash or kind. Once some members give, it becomes imperative for all members to follow suit if the sense of society is to be maintained. Members of a society do common things. They may not think and feel alike, but there is viva force that compels members who identify with a society to behave in a uniform way. One respondent from G.M.M. clearly stated that because everyone at their church seeded, he could not be left out. He stated that because he was a member of that church, failing to seed as others did could be viewed as discord. For him to feel a sense of membership, a sense of belonging, he had no option but to seed like others. Seeding for him socially bound him to the church.

This theme kept on recurring with other respondents. A female respondent from A.F.M. poignantly pointed out that it was quite embarrassing for one to fail to seed when others did so at the church. She argued that in order to keep in touch with others, which is cohering with others, she was obliged to seed as well. Asked whether seeding for her had any benefits, she confirmed that it had, in that she found herself among others. Her seeding was meant to keep community with others. Her preoccupation with seeding was to ensure she belonged to the community of A.FM. So, the need to belong entices people to seed in church. Émile Durkheim (1912) argues that religion is adhesive; it brings people together socially. For him religion is eminently social.

\section{Religious Factors}

Spirituality is at the centre of religious people's activities. Everything a religious person does has a spiritual explanation. Seeding has religious repercussions. One respondent animated that he was seeding for spiritual edification. He stated that seeding was biblical. The argument is that the more 
one sows the closer one becomes to the numinous, object of belief. The less one sows the more distant one becomes. He stated thus,

Kupa kumphatso yaMwari kusima kukwededza munthu padhuze naMwari. Ukasapa ukama hwako naMwari hwakaita zinyekenyeke [Sowing in the house of the Lord brings one closer to the Lord. When one does not sow in the house of the Lord, one's relationship with the Lord is loose].

This implies that one solidifies one's relationship with the numinous by seeding. This understanding was prevalent among many respondents. They argued that seeding made them spiritually grow in the Lord. They indicated that seeding was a sign of a mature Christianity, a practical Christianity. They gave examples of senior members of their respective churches who gave abundantly to the church as a sign of maturity. In comparison, young members of the church give less than elderly ones, the reason being that the youth is more critical of seeding than the elders. For the respondents, sowing in the house of God spiritually gratifies and edifies one.

\section{Economic Factors}

These factors have made seeding in the church quite controversial. While people associate seeding with the gospel of prosperity, it has become a contentious issue within the church itself. It has become debatable, especially with the new wave of Pentecostal movements in Zimbabwe. While advocates of seeding perceive it as economically empowering for the church, Man of God and the church membership, there are condescending voices that question the sincerity of the church and Man of God asking people to sow in the church. Voices of suspicion are premised on what Togarasei sums up in this:

To get rich, members of Pentecostal churches are taught to 'sow seeds' of prosperity. This analogy of sowing and reaping is derived from 2 Corinthians 9:6-11. One should sow generously in order to have a big harvest. Giving to the church is equated to giving God, so the measure you give is the measure you will get back. The churches, therefore, receive huge sums of money from members (Togarasei 2010:31). 
The suspicion emanates from the question: To what use are the huge sums of money put? Speculation is rife that the money ends up in a few hands, yet it has been 'donated' in the spirit of the church. Some sceptics have even asked: Who is the church? Is it the Man of God? These are some of the questions that have made sowing/giving in the church a hotly debated phenomenon.

Notwithstanding, those who sow in the church have economic reasons. The respondents (A.F.M., P.H.D. and G.M.M.) indicated that when a member gave to the church and as the church got edified both spiritually and materially, the giver was not left from this edification. One metaphor that was repeatedly used by most of them was of the traditional gourd [mukombe] which remains oily after it has been used to collect oil from a pot. Mukombe ukachera mugate rine mafuta unosara wakanunirawo [loosely translated as a traditional gourd that collects from an oily pot remains oily as well]. This implies that as the church gets material accumulation, the members who seed get rich too. A female respondent from G.M.M. said,

When we seed, we know for sure that God will bless us with prosperity. Examples in this church are plenty of people we have seen seeding with meagre resources but now they have been blessed with cars and houses. We are often told by the Man of God in this church to seed and it is working for us.

They do not care whether the church syphons from them, since the belief is that they also get rich. It was very clear from the respondents that social, religious and economic factors of seeding were the driving force for seeding. However, the economic factors were more prevalent than others as they came out prominently under the notion of prosperity gospel.

\section{'Man/ Woman of God'}

From the interviews conducted, it was found that many of the respondents held 'Man/Woman of God' in awe and he/she was generally perceived as a largerthan- life human being. A.P.H.D. respondent stated that a 'Man/Woman of God' was God's anointed one [muzodziwa waMwari]. For another from G.M.M., 'Man/Woman of God' was mutumwa waMwari [messenger of God]. More titles came out such as muporofita [prophet], baba [father], munhu waMwari [Man/Woman of God]. The titles point to one common denominator; 


\section{Tenson Mabhuya Muyambo}

that is, all respondents revered and held the 'Man of God' in high esteem. He was, in their view, not ordinary, but a being who was called to perform God's will to the congregants. This resonates with Gunda and Machingura's (2013) views when they argue that the 'Man of God' is an outstanding individual, and Glover (2006: 452) states that a 'Man of God' is an individual who is literally 'above men'. This brings a sense of a 'mortal above other mortals' (Gunda \& Machingura 2013: 19). In a 'Man of God', is an embodiment of the mortal man and the immortal nature of God. This explains why respondents held 'Man/Woman of God' in awe, for in him/her God is personified. The theological ramifications of such a portrayal of 'Man/Woman of God' is that whatever he says is accepted without question. Questioning him/her is tantamount to questioning the object of worship, the numinous.

\section{Analysis of Findings \\ Seeding is Biblical}

The motif that seeding or sowing in the church is biblical is without doubt. All the interviewees from A.FM., P.H.D. and G.M.M. indicated that it was biblical by referring to verses in the bible. The argument then is: if seeding is biblical, it implies that it is Godly. If it is Godly, then believers in God are exhorted to follow God's commandment. The question is: Is seeding in the church religious gullibility? This question poses serious challenges in that it is double-barrelled. On the one hand, believers seed because it is Godly to do so. On the other hand, their seeding has failed the test of accountability in several churches. This culminates in another question: If the church fails the test of accountability in the church's financial affairs, who then is to blame? Should the believers continue to seed when what they seed is not accounted for? These questions can be addressed when we look at the position of believers insofar as their seeding is concerned. To look at these questions from positions other than the believers defies the phenomenology of religion perspective adopted for this study, yet scholarship, as this study is, is about posing critical questions.

Admittedly, believers' seeding in some churches have come to nothing. Most church leaders have been in the firing line for encouraging seeding for their personal gain. Most scholars critical about the gospel of prosperity in Zimbabwe are Biri (2012), Tograrasei (2010), Gunda and Machingura (2013). These scholars' understanding of the gospel of prosperity is that it is meant to enrich few individuals in the church. Their argument is 
that those who seed continue to plummet in poverty while a handful, especially church leaders are getting richer and richer. While their arguments are valid, we may want to ask again this question once posed by Chitando, Mapuranga and Taringa (2014): On top of which mountain does one stand to judge religion? Are seeding sceptics doing so as insiders or outsiders? The sceptics seem to have gone beyond the dictates of the phenomenology of religion perspective. They have gone 'beyond describing the phenomena of religion. They have moved into the realm of evaluation' (Chitando et al. 2014). Analysing those who seed as gullible belongs to advocacy and activism, not scholarship, phenomenologists of religion would argue. The believers stated why they seed, which among others, are the benefits that accrue with seeding. Who these sceptics are, who want to speak on behalf of the believers themselves, remains a big challenge. Should scholarship, especially scholars of religion whose persuasions are phenomenology of religion inclined to stop at thick descriptions at the expense of judging some of the religious beliefs and practices such as seeding in the church? These questions point to the fluidity of the concept under discussion. While believers may see it as Godly and noble, onlookers perceive seeding as a sign of religious gullibility where believers are syphoned off their hard-earned cash in the name of sowing in the church. Without wanting to sound judgmental, some events in the church leave onlookers surprised at the level of meekness displayed by the believers. The way they respect the 'Man of God' leaves onlookers with no option but to label them as being gullible.

\section{'Man of God' is Superhuman}

The tag 'Man/Woman of God' creates an aura of not only authority but unquestionable power. Because of this unquestionable authority and power, the 'Man of God' is a 'divine-human being' (Gunda \& Machingura 2013:22). The belief is that all things that God can do can also be done by the 'Man of God'; hence the idea that God is not far away from the 'Man of God' (Glover 2006). This understanding of 'Man of God' makes him attract large crowds of people. Examples of such 'Men of God' in Zimbabwe include Emmanuel Makandiwa, Walter Magaya and many others.

Since followers of the 'Man of God' look up to him for all things, including healing, deliverance and prophecy, they believe and trust in everything the 'Man of God' does and says. What he does and says are not his 
but of Him who sends him. This explains why some followers of the 'Man of God' engage in what onlookers perceive as bizarre happenings such as congregants who are asked to eat grass and then unquestioningly do that. One incident that provoked onlookers happened in South Africa when Pastor Lesego Daniel of Rabboni Centre Ministries ordered dozens of followers to drop to the floor and eat the grass at his ministry in Garankuwa, north of Pretoria after being told it will 'bring them closer to God' (Reilly 2014).

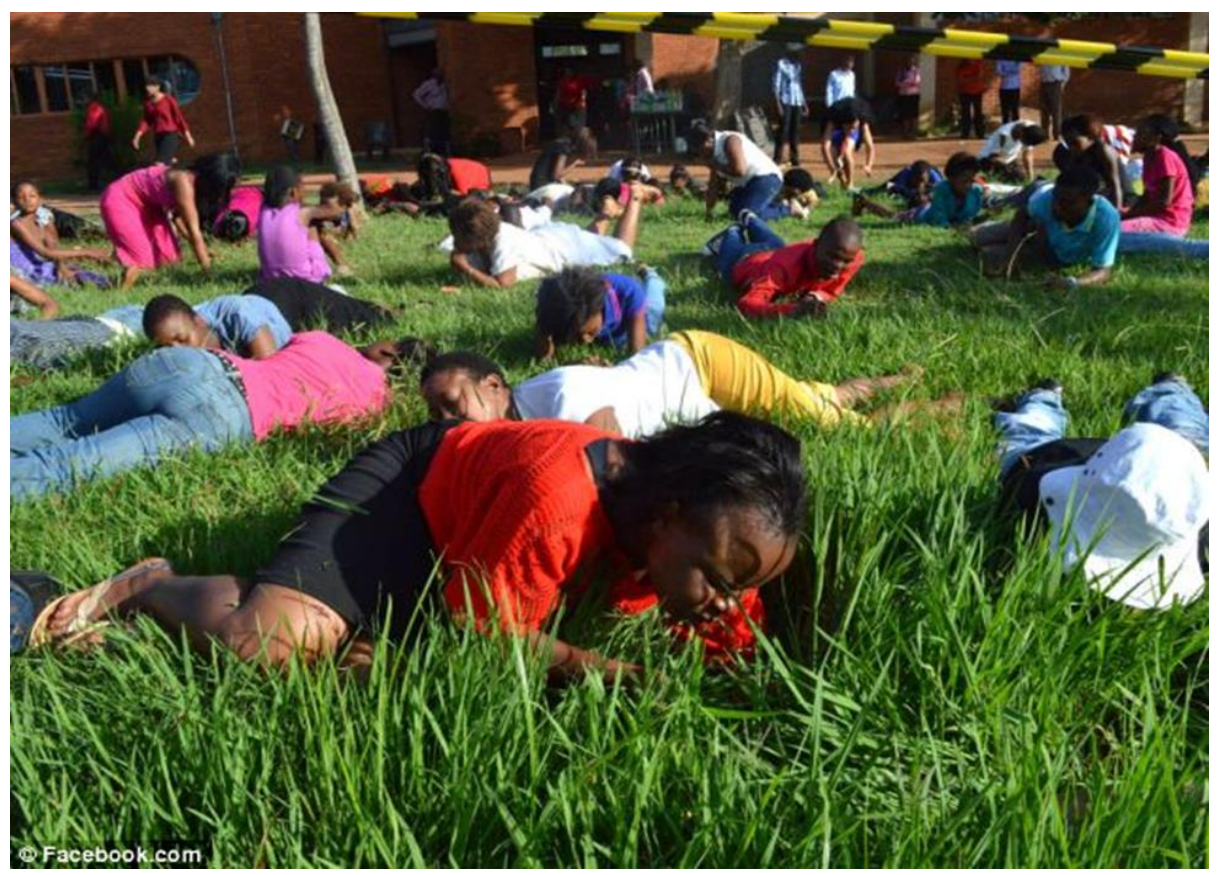

A South African preacher made his congregation eat grass to 'be closer to God'.

A participant is quoted to have said, 'Yes, we eat grass and we're proud of it because it demonstrates that, with God's power, we can do anything'. The incident invited a lot of criticisms from onlookers who felt that this was a violation of human rights. Is the incident a case of gullibility? If the participants boldly confess that they did that, not out of their senses, but knowingly, who are then these onlookers who simply pass judgment on events whose essence 
they are not privy to? The questions above bring us to the point that matters of spirituality are not easy ones in the public domain; hence outsiders cannot comprehend these happenings.

While from the believers' point of view there is nothing amiss in followers who take orders from their 'Man of God', it boggles the mind for onlookers to keep quiet about such happenings. The moment they pass judgment, phenomenologists accuse them of going beyond descriptions of religious phenomena. Scholars of religion and researchers alike are left in a quandary whether they should evaluate or not what believers tell them. When they evaluate such religious phenomena such as eating grass or feeding on snakes they are asked: On top of which mountain are they standing to judge a congregation that is simply following an instruction from the 'Man of God' who does not resemble himself but the power beyond him; that is, God. Who are these followers then to refuse God's orders? In any case the actions are meant to serve and save the followers, to 'bring them closer to God'.

\section{Are Congregants' Actions Gullible?}

It must be stated that religious matters have been heavily contested from time immemorial. Karl Marx is quoted in Chitakure (2016) as having been sceptical about religious behaviour by religious people. The reason for Marx's scepticism emanates from his experiences with religious people. His major argument is that 'religion is the opium of the masses', implying that religion enslaves and imprisons its followers. Religion, in Marx's view, makes religious people docile. They no longer question things. Arguing from a working-class perspective, Marx equates religion to a drug (opium) that blinds people from seeing that they are exploited by capitalists. In Marx's view the believers who are duped or made to eat grass or buy bricks in the hope of having their own houses are being gullible. Using IPA, I submit that such 'sheepish' behaviour cannot be condoned.

Given such truisms, what then must the scholar of religion do? Should he/she stop at descriptions of religious phenomena or go beyond that and evaluate religious events? Chitando et al.'s (2014) submissions that 'the search for uncontested mountains upon which one may stand to judge religion continues unabated' is insightful in a bid to answer the above questions. Phenomenologically, the understanding that what the believers do during seeding (which could be giving money, doing voluntary work in the church or eating grass as 


\section{Tenson Mabhuya Muyambo}

is the case above) should be described as such, without evaluation needs further analysis. The phenomenology of religion approach adopted for the study emphasises the 'sole right of the believer' but that does not mean the researcher should be a tabula rasa for the believers to pour in their opinions/ views/ experiences. Scholars/researchers are not uncritical consumers of information. I argue here and concur with Chitando (1998), who submits that there is need, even in the use pf phenomenology of religion, to engage in a questioning spirit. Education, after all, is meant to empower. The congregants' behaviour cannot be spared this questioning spirit, especially by scholars like me.

While being mindful of the demands of phenomenology of religion, it will be folly for any scholar or researcher to stop at an accurate description. With this in mind, it is undeniable that some of the activities that followers of the 'Man of God' do leave a lot to be desired. At times, their actions and behaviour defy logic. It is at this point that onlookers' criticisms of religious people's actions and behaviour call for a closer analysis (a skill that scholars cannot desist from).

The believer's point of view is commendable, but reality and experience have shown that believers suffer at the hands of 'Man of God'; but fail to complain due to the awe associated with the 'Man of God'. Many cases are reported where people are duped of large sums of money by 'Men/Women of God', only to realise afterwards that they have been duped. About two years ago, a case was heard in the courts where congregants were suing prophet Makandiwa for 'fake prophecies' (The Sunday Mail, Religion, 06 August 2017). Chitando (2013: 248) criticises church leaders who manipulate 'religious beliefs to confuse their followers while they accumulated resources at their expense'. The overuse of verses on seeding as well as those that portray the 'Man of God' as a 'touch not the anointed' cower believers into naivety. Once cowered the believers can no longer ask for accountability in the financial matters of the church. They are duped in the name of doing the work of God. Asking for financial reports in the church is construed as a lack of trust, an unaccepted position in some church denominations.

Eating of grass cited above cannot escape the critical eye of a scholar of religion or researcher. Although the believers themselves testified that they were happy to do it in order to get closer to God, such naivety defies natural laws of logic/reason. How can people believe in eating grass as a way to get closer to God? In what ways are the two related?

To further illustrate how religious people are gullible, a story of a 
young woman going to church at night who met an 'angel' from God went viral on social media. In the story a boy waylaid a young woman on her way to church. The boy had a torch and he used it to confuse the young woman. The light from the torch appeared as if it was a light from the angel, which ordered the young woman to undress since the 'angel' wanted to be intimate with her. The young woman, thinking it was a true angel, undressed as was commanded by the 'angel'. She was raped in that incident only to realise later that she was raped by a local boy. Although she reported the matter to the police and the boy was arrested, her religious naivety is beyond comprehension.

Many stories of this nature are often reported in the media. Most women are duped especially by purported prophets from the Apostolic movements. The story, 'Johane Masowe Prophet rapes woman' (Harare 24, 31 December 2012) says it all. Desperate women are raped in the guise of being healed or exorcised of evil spirits that make them barren. The desperate women are told to meet the 'Man of God' in the forest where there is no-one. As if that is not enough, they are asked to remove their clothing as the 'prophet' wants to perform his exorcism activities on her body while naked. The woman falls prey to the unscrupulous 'prophet' or madzibaba. One may ask: Is this not naivety that is explained religiously? One wonders where one's senses would have gone to undress before a man in the middle of a forest.

\section{The Argument}

The issues of material/spiritual seeding and 'Man of God' remain contested even in the above discussion. Advocates and practitioners of seeding maintain that seeding is beneficial in their day-to-day lives. Their argument is summarised by an interviewee who questioned why it was right when members of political parties pledge (synonymous to seeding), but wrong when Christians seed in the church This resonates with Bulla's (2015) views. Using a phenomenology of religion perspective, scholars of religion and researchers have no right to judge religious phenomena like seeding and the 'Man of God' title. Theirs are accurate descriptions of religious phenomena. They must be guided by the dictum, 'The believer is always right'. If believers see no evil in their seeding and it works for them, no one should judge. 'On top of which mountain does one stand to judge seeding in the church and the role of the 'Man of God'? What this implies is that if believers find sense in their seeding or eating grass, so be it. 
On the contrary, scholars of religion and researchers are critical by nature. Even though phenomenology of religion encourages them to desist from judging, their profession has trained them to be inquisitive as they seek to explain why phenomena behave the way they do. The bid to answer the what, how and why questions that often confront scholars and researchers compels them to be critical. They cannot stop at accurate descriptions of phenomena, but go beyond to evaluate. This is the essence of scholarship. So, questioning material/spiritual seeding as religious gullibility depends on the 'mountain one stands' on. My argument is that while believers feel that what they are doing is normal, scholars and researchers alike have an obligation to inform society correctly and thus cannot afford the luxury of being uncritical.

\section{Conclusion}

Labelling seeding in the church as religious gullibility is heavily contested. It depends on the mountain one stands on. In this chapter, I have examined how congregants of several denominations (A.F.M., P.H.D. and G.M.M.) perceive seeding as well as the 'Man of God'. The chapter argues that it is the believers' perceptions that determine how they behave towards the notion of seeding and the idea of the 'Man of God'. I have highlighted that if the approach adopted for the study is the phenomenology of religion it is prudent to listen to the believers, for the believers are always right. If the believers justify seeding, a phenomenologist cannot dispute that. Scholars of religion and researchers alike need to tread cautiously when dealing with religious phenomena. Their mandate is to describe accurately and not to evaluate. But as evident in the study, evaluation is inevitable. The need to strike a balance between desisting from judging and the penchant to evaluate poses challenges for phenomenologists. Using IPA strikes a balance, where believers remain steadfast in their beliefs, while scholars/researchers call a spade a spade. Gullibility in all its forms is bad practice, for it violates certain fundamental human rights whose recourse is often sought in courts.

\section{References}

Biri, K. 2012. The Silent Echoing Voice: Aspects of Zimbabwean Pentecostalism and the Quest for Power, Healing and Miracles. Available at: 
http://uir.unisa. ac.za/handle/10500/6609

(Accessed on 24 November 2018.)

Bulla, F. 2015. Seeding: Manipulation or the Truth? The Sunday Mail. Religion. 15 March. Available at:

https://www.sundaymail.co.zw/seeding-manipulation-or-the-truth (Accessed on 30 November 2018.)

Chimuka, T.A. 2017. The Threat of Gullibility: Faith and Christian Behaviour in Southern Africa. Oral History Journal of South Africa 5,1: 49 - 63.

https://upjournals.co.za/index.php/OHJSA

Chitakure, J. 2016. The Pursuit of the Sacred: An Introduction to Religious Studies. London: Wipf and Stock Publishers.

Chitando, A. 2013. Reading Zimbabwean Writers on Churches and Prophets: Insights from Maredza, Mungoshi and Chinodya. In Chitando, E., R.M. Gunda \& J. Kügler (eds.): Prophets, Profits and the Bible in Zimbabwe. Bamberg: University of Bamberg Press.

Chitando, E. 1998. The Phenomenological Method in a Zimbabwean Context: To Liberate or Oppress? Zambezia XXV,i: 99 - 114.

Chitando, E., M. Manyonganise \& O.B. Mlambo 2013. Young, Male and Polished: Masculinities, Generational Shifts and Pentecostal Prophets in Zimbabwe. In Chitando, E., R.M. Gunda \& J. Kügler. (eds.): Prophets,

Profits and the Bible in Zimbabwe. Bamberg: University of Bamberg Press.

Chitando E., T.P. Mapuranga \& N.T. Taringa 2014. On Top of which Mountain does One Stand to Judge Religion? Debates from a Zimbabwean Context. Journal for the Study of Religion 27,2: 115 - 136. Available at: http://www.scielo.org.za/pdf/jsr/v27n2/07.pdf; and, https://www.researchgate.net/publication/317449804_On_top_of_which mountain does one stand to judge religion Debates from a Zimba bwean_context

(Accessed on 28 November 2018).

Conrad, P. 1987. The Experience of Illness: Recent and New Directions. Research in the Sociology of Health Care 6:1-31.

De Vaus, D. 2002. Surveys in Social Research. $5^{\text {th }}$ Edition. London: Routledge. https://doi.org/10.4135/9781446263495

Durkheim, E. 1912. The Elementary Forms of the Religious Life. New York: Dover Publications, INC.

Glover, N. 2006. Elijah versus the Narrative of Elijah: The Contest between 
the Prophet and the Word. Journal for the Study of the Old Testament 30,4: 449 - 462. Available at:

http://citeseerx.ist.psu.edu/viewdoc/download?doi=10.1.1.

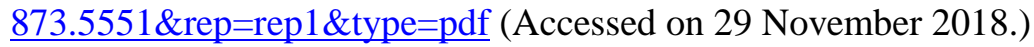

https://doi.org/10.1177/0309089206066319

Gunda, R.M. \& F. Machingura 2013. The 'Man of God': Understanding the Biblical Influence on Contemporary Mega-Church Prophets in Zimbabwe. In Chitando, E., R.M. Gunda \& J. Kügler (eds.): Prophets, Profits and the Bible in Zimbabwe. Bamberg: University of Bamberg Press.

Harare 24. 2020. 31 December.

Reilly, J. 2014. Congregation Eat Grass to be Closer to God. Mail Online 10 January.

Smit J.A. \& M. Osborn. 2007. Interpretive Phenomenological Analysis.

Available at: http://med-fom-familymed-

research.sites.olt.ubc.ca/files/2012/ 03/IPA Smith_Osborne21632.pdf

(Accessed on 21 August 2019).

The Sunday Mail, Religion. 2017. 06 August.

Togarasei, L. 2010. Churches for the Rich? Pentecostalism and Elitism. In

Togarasei, L. \& E. Chitando (eds.): Faith in the City: The Role and Place of Religion in Harare. Uppsala: Swedish Science Pr.

Dr. Tenson Mabhuya Muyambo

Gender and Religion

Department of Teacher Development

Great Zimbabwe University

Masvingo

Zimbabwe

tmuyambo@gzu.ac.zw 